\title{
Weathering Resistance of Poplar Wood Coated by Organosilane Water Soluble Nanomaterials
}

\section{Otpornost prema vremenskim utjecajima topolovine premazane vodenom otopinom organosilana u nanoveličinama}

\author{
Original scientific paper • Izvorni znanstveni rad \\ Received-prispjelo: 7. 2. 2018. \\ Accepted-prihvaćeno: 27. 11. 2018. \\ UDK: $630 * 814.111 ; 630 * 829.5$ \\ doi:10.5552/drind.2018.1801
}

\begin{abstract}
The potential use of organosilane nanomaterials (nano-zycosil and nano-zycofil) for improving the weathering resistance of poplar wood was evaluated in comparison to common clear coatings (nitrocellulose and polyester lacquer). A $250 \mu \mathrm{m}$ coating layer was applied by an automatic film applicator at the speed of 150 $\mathrm{mm} / \mathrm{s}$. The coated specimens were exposed to a $1000 \mathrm{~W}$ xenon arc light source at $65 \%$ relative humidity and temperature of $20^{\circ} \mathrm{C}$ inside a weather-o-meter for 1440 hrs. Among coating materials, nano-zycosil showed the best performance to improve the weathering resistance. Compared to the lacquer-coated samples, the roughness of nanoparticle-coated ones was less affected by weathering. Contact angle measurements indicated that nanozycosil coating had a pronounced decreasing effect on the surface wettability. The combined analyses of SEM and EDX demonstrated that the nanoscale silane layer covered the whole wood surface homogeneously, whereas nitrocellulose and polyester coatings were deposited preferentially in the surface depressions.
\end{abstract}

Keywords: clear coatings, organosilane nanomaterials, weathering, wood

\begin{abstract}
SAŽETAK • U radu je prikazano istraživanje mogućnosti uporabe organosilana u nanoveličinama (nano-zycosil i nano-zycofil) za povećanje otpornosti topolovine na vremenske utjecaje u usporedbi s uporabom klasičnih prozirnih premaznih materijala (nitroceluloznoga i poliesterskoga premaza). Sloj premaza od 250 um nanesen je strojno, brzinom $150 \mathrm{~mm} / \mathrm{s}$. Premazani su uzorci 1440 sati bili izloženi izvoru svjetlosti ksenonske svjetiljke od $1000 \mathrm{~W}$ pri relativnoj vlazi zraka od $65 \%$ i na temperaturi od $20^{\circ} \mathrm{C}$. Od premaznih materijala nano-zycosil se pokazao najboljim za povećanje otpornosti na vremenske utjecaje. U usporedbi s uzorcima obrađenim klasičnim premaznim materijalima, hrapavost nanopremaza bila je manje uvjetovana izlaganjem vremenskim utjecajima. Mjerenja kontaktnog kuta pokazala su da premaz nano-zycosilom znatno utječe na smanjenje kvašenja površine. Kombinirane analize SEM i EDX potvrdile su da sloj silana u nanoveličini ravnomjerno prekriva površinu drva, dok je sloj nitroceluloznoga i poliesterskog premaza u udubljenjima na površini deblji.
\end{abstract}

Ključne riječi: prozirni premazi, organosilani nanoveličine, izlaganje vremenskim utjecajima, drvo

\footnotetext{
Authors are assistant professor and associate professor at Department of Wood and Paper Science and Technology, Faculty of Natural Resources, University of Tehran, Karaj, I.R. Iran.

Autori su docent i izvanredni profesor Odsjeka za znanost i tehnologiju drva i papira, Prirodoslovno matematički fakultet, Sveučilište u Teheranu, Karaj, IR Iran.
} 


\section{INTRODUCTION}

\section{UVOD}

Wood surfaces exposed to outdoor conditions are rapidly degraded due to the combined action of weather factors, such as oxygen, ultraviolet light and relative humidity (RH). Several paints and varnishes are commonly used as coating materials to prevent the degradation. However, wood coated with common clear coatings is still susceptible to photo discoloration (Lung Chou et al., 2008; Bulian et al., 2017). The photo discoloration is unavoidable even if wood is coated with non-yellowing or durable clear coatings, such as aliphatic polyurethane ones (Chang and Chou, 1999). The coating performance depends on several factors, in particular the substrate, the coating system and the interactions between them (Bulian and Graystone, 2009). Nowadays, coating is an area of significant research in nanotechnology. Nanoparticle based coating systems can provide better weathering resistance (Clausen et al., 2010; Nguyen-Tri et al., 2018) and conservation than the conventional techniques because of very small pigment particles with very high specific surface. Some appropriate nanoparticles, such as silica $\left(\mathrm{SiO}_{2}\right)$, alumina $\left(\mathrm{Al}_{2} \mathrm{O}_{3}\right)$ (Busseya et al., 2018; Mori et al., 1998; Powell et al., 1997) and $\mathrm{TiO}_{2}$ (Nanetti, 2006; Li et al., 2005) have been previously used to improve the wood weathering resistance. For example, Veronovski et al. (2013) found that the surface treatment of wood with nano- $\mathrm{TiO}_{2}$ (rutile) incorporated in water-based acrylic coatings improves the weathering resistance. Organosilane nanomaterials have been mainly developed for waterproofing of wood because they can block the pores by agglomeration and prevent the penetration of water into wood (Tshabalala and Gangstad, 2003; Godnjavec et al., 2012). For concrete, Nanozycosil with size of up to $6 \mathrm{~nm}$ can enhance the waterproofing property of the surfaces by filling the microcracks and nanopores (Taghiyari, 2013). Gholamiyan et al., $(2012,2016)$ also reported that the organosilane nanomaterials (zycosil and zycofil) can be used as water vapor diffusion retarders for wood. The present study was, therefore, conducted to evaluate if organosilane nanoparticles can significantly contribute to improvement of weathering resistance of wood.

\section{MATERIALS AND METHODS 2. MATERIJALI I METODE}

\subsection{Wood sampling and coating materials}

2.1. Uzorkovanje drva i premazni materijali

Flat-sawn boards of poplar wood (Populous nigra) with dimensions of 50 by 100 by $200 \mathrm{~mm}$ (T, R and $\mathrm{L}$ directions, respectively) at moisture content of $12 \%$ were selected for the study. Sealer and nitrocellulose lacquer and polyester lacquer were used as clear coatings. They were purchased from Dorsa Chemistry (Brilliant) Co. The technical properties of the lacquers are summarized in Table 1. Organosilane water soluble nanomaterials (nano-zycosil and nano-zycofil) were purchased from Zydex Company. The most important properties of the nanomaterials are presented in Table 2.

\subsection{Coating methods}

\subsection{Metode nanošenja premaznog materijala}

The wood surfaces were sanded with 150-grade sandpaper before coating. Six different coating systems were applied as shown in Table 3. A $250 \mu \mathrm{m}$ wet precure coating layer was applied by an automatic film applicator at the speed of $150 \mathrm{~mm} / \mathrm{s}$. The nanomaterialcoated samples were oven dried at temperature of 103 $\pm 2{ }^{\circ} \mathrm{C}$ for $24 \mathrm{~h}$, and the others were dried in a conditioned room $\left(\mathrm{T}=25^{\circ} \mathrm{C}\right.$ and $\left.\mathrm{RH}=65 \%\right)$ for about 20 minutes. The lacquers were diluted by a lacquer thinner (1:2) before application.

\subsection{Weathering test}

2.3. Izlaganje vremenskim utjecajima

The coated specimens were exposed to a $1000 \mathrm{~W}$ xenon arc light source at $65 \% \mathrm{RH}$ and chamber temperature of $30{ }^{\circ} \mathrm{C}$ in a weather-o-meter for $1440 \mathrm{hrs}$.

Table 1 Technical properties of nitrocellulose lacquer and polyester lacquer

Tablica 1. Svojstva nitroceluloznoga i poliesterskoga premaznog materijala

\begin{tabular}{|l|c|c|c|c|c|}
\hline \multicolumn{1}{|c|}{$\begin{array}{c}\text { Coating type / Vrsta } \\
\text { premaznog materijala }\end{array}$} & $\begin{array}{c}\text { Viscosity at 25 } \\
{ }^{\circ} \mathbf{C} / \text { Viskoznost } \\
\text { pri } 25^{\circ} \mathrm{C}\end{array}$ & $\begin{array}{c}\text { Percent solids } \\
\text { Udio suhe tvari }\end{array}$ & $\begin{array}{c}\text { Density at } 25{ }^{\circ} \mathbf{C} \\
\text { Gustoća pri } 25{ }^{\circ} \mathrm{C}\end{array}$ & $\begin{array}{c}\text { Color (Gard- } \\
\text { ner) } / \text { Boja } \\
\text { (Gardner) }\end{array}$ & $\begin{array}{c}\text { Flash point, }{ }^{\circ} \mathrm{C} \\
\text { Točka zapaljenja, }{ }^{\circ} \mathrm{C}\end{array}$ \\
\hline $\begin{array}{l}\text { Nitrocellulose lacquer } \\
\text { nitrocelulozni premazni } \\
\text { materijal }\end{array}$ & $16-38 \mathrm{~Pa} \cdot \mathrm{s}$ & $21 \pm 1$ & $0.94 \pm 0.01$ & 3 max & $\leq 20$ \\
\hline $\begin{array}{l}\text { Polyester lacquer poliesterski } \\
\text { premazni materijal }\end{array}$ & $10-25 \mathrm{~Pa} \cdot \mathrm{s}$ & $30 \pm 1$ & $0.94 \pm 0.01$ & 3 max & $\leq 20$ \\
\hline
\end{tabular}

Table 2 The most important information on used nanomaterials

Tablica 2. Najvažniji podatci o primijenjenim nanomaterijalima

\begin{tabular}{|c|l|l|}
\hline Property / Svojstvo & Zycosil & Zycofil \\
\hline Size / veličina & $10-30 \mathrm{~nm}$ & $90-300 \mathrm{~nm}$ \\
\hline Color / boja & Pale yellow / bljedožuta & Yellow / žuta \\
\hline Density / gustoća & $1.7\left(\mathrm{~g} / \mathrm{cm}^{3}\right)\left(25^{\circ} \mathrm{C}\right)$ & $2.5\left(\mathrm{~g} / \mathrm{cm}^{3}\right)\left(25{ }^{\circ} \mathrm{C}\right)$ \\
\hline Flash point / točka zapaljenja & More than $/$ iznad $100{ }^{\circ} \mathrm{C}$ & $\mathrm{More}$ than $/$ iznad $100{ }^{\circ} \mathrm{C}$ \\
\hline Auto-ignition temperature / temperatura samozapaljenja & More than $/$ iznad $200^{\circ} \mathrm{C}$ & $\mathrm{More}$ than $/$ iznad $150^{\circ} \mathrm{C}$ \\
\hline Viscosity / viskoznost & $0.5-1 \mathrm{~Pa} \cdot \mathrm{s}\left(25^{\circ} \mathrm{C}\right)$ & $0.2-0.7 \mathrm{~Pa} \cdot \mathrm{s}\left(25^{\circ} \mathrm{C}\right)$ \\
\hline
\end{tabular}


Table 3 Guide for coating systems

Tablica 3. Oznake sustava premaznih materijala

\begin{tabular}{|c|c|}
\hline $\begin{array}{c}\text { Coating type / Vrsta } \\
\text { premaznog materijala }\end{array}$ & $\begin{array}{c}\text { Coating materials } \\
\text { Premazni materijal }\end{array}$ \\
\hline Control & None \\
\hline CZ & nano-zycosil \\
\hline CZF & nano-zycofil \\
\hline CZZF & nano-zycosil+ nano-zycofil \\
\hline CPS & Clear polyester lacquer \\
\hline CSC & sealer + nitrocellulose lacquer \\
\hline CSC+CPS & $\begin{array}{c}\text { sealer + nitrocellulose lacquer }+ \\
\text { polyester lacquer }\end{array}$ \\
\hline
\end{tabular}

\subsection{Color measurement}

\subsection{Mjerenje boje}

Spectrophotometry was applied to measure brightness $\left(L^{*}\right)$, redness $\left(b^{*}\right)$ and yellowness $\left(a^{*}\right)$ variables of specimens in the CIE-LAB system before and after exposure to the accelerated weathering. Ten boards were tested for each type of coating system. The spectrophotometry was performed using a miniscan EZ spectrophotometer with the aperture diameter of 25 $\mathrm{mm}$ and with a standard illuminant D65 and a $10^{\circ}$ standard observer. The parameters of $\Delta E^{*}$ (color difference), $C^{*}$ (color saturation) and $h^{*}$ were calculated using the following equations:

$$
\begin{gathered}
C^{*}=\sqrt{\left(a^{*}\right)^{2}+\left(b^{*}\right)^{2}} \\
\Delta E^{*}=\sqrt{\left(\Delta a^{*}\right)^{2}+\left(\Delta b^{*}\right)^{2}+\left(\Delta L^{*}\right)^{2}} \\
h^{*}=\operatorname{Arctan}\left(b^{*} / a^{*}\right)
\end{gathered}
$$

\subsection{Measuring the surface roughness}

\subsection{Mjerenje hrapavosti površine}

A Mitutoyo SJ-201P instrument was employed for measuring the surface roughness. Three roughness parameters characterized by ISO 4287 standard (1997), namely average roughness $(R \mathrm{a})$, mean peak-to-valley height $(R z)$, and maximum peak-to-valley height $(R y)$ were considered to evaluate the surface characteristics of coatings before and after weathering.

\subsection{Determination of wettability}

2.6. Ispitivanje kvašenja

The wetting behavior of coated samples conditioned at $65 \% \mathrm{RH}$ and $20{ }^{\circ} \mathrm{C}$ was characterized by static contact angle (CA) measurement and deionized water as test liquid. The CA values were determined by sessile drop method using a KSV Cam-101 Scientific Instrument (Helsinki, Gottingen University, Germany). The measurements were carried out for 1 and $10 \mathrm{sec}-$ onds after deposition of the water drop on the surface. The average CA value was obtained with five drops for each sample.

\subsection{SEM, EDX and ATR-FTIR studies} 2.7. SEM, EDX i ATR-FTIR istraživanje

The surface morphology of coated samples was characterized by a scanning electron microscopy (SEM). The surface chemical composition of speci- mens was examined by energy dispersive X-ray analysis (EDX). Fourier transform infrared spectrophotometer (ATR-FTIR; Bruker model Confocheck) was also applied to identify the formed chemical bonds.

\section{RESULTS AND DISCUSSION \\ 3. REZULTATI I RASPRAVA}

\subsection{Color changes}

3.1. Promjene boje

Table 4 shows $L^{*}, a^{*}$ and $b^{*}$ values and their changes on various coated wood samples due to weathering. Before weathering, $L^{*}$ for uncoated specimens was greater than that for all coated ones. The color parameters $\left(L^{*}, a^{*}\right.$ and $\left.b^{*}\right)$ of nano-zycofil (CZF)- and nano-zycosil (CZ)-coated specimens were found to be different. The color change of weathering for $\mathrm{CZ}$ was less than that for $\mathrm{CZF}$. One of the main reasons for color change of clear coatings is the discoloration of wood substrate, affected by its individual chemical components, such as extractives (Fengel and Wegener, 1984). After coating, $b^{*}$ and $a^{*}$ decreased for all coatings, except CZ. Sigh et al. (2008) and Lung Chou et al. (2008) also reported a similar result for yellowing of clear coatings. After weathering, the least change in lightness index was observed for $\mathrm{CZ}$ and $\mathrm{CZZF}$ coatings. The lightness of $\mathrm{CZ}$ and $\mathrm{CSC}+\mathrm{CPS}$ coatings dropped from 75.6 to 74.3 and from 78.1 to 67.5 , respectively. After weathering, all coatings except $\mathrm{CZ}$ and CZZF were darker than the control sample as shown by the decreased $L^{*}$ values (see Table 4 ). This $L^{*}$ reduction is due to destruction of chemical bonds and photochemical degradation of cross-linking reactions at the surface coatings (Vlad Cristea et al., 2011). After weathering, all coatings are more reddish and yellowish (indicated by increased $b^{*}$ and $a^{*}$ values, respectively, in Table 4) than the control sample (Tsuchikawa et al., 2003 and Pastore et al., 2004). The least change in $a^{*}$ and $b^{*}$ parameters was observed for CZZF. After coating, CZ showed the least color change $(\Delta E)$. According to the measured color data, it can be noted that all coatings are more red, yellow and saturated $\left(c^{*}\right)$ than the uncoated wood both before and after weathering (Table 5). The color saturation after weathering ranged from 48.7 for sealer and nitrocellulose lacquer-coating to 35.6 for uncoated wood. Similar results were also found for hue angle $\left(h^{*}\right)$.

\subsection{Surface roughness}

3.2. Hrapavost površine

The surface roughness values ( $R \mathrm{a}, R \mathrm{z}$ and $R \mathrm{q})$ for each coating are depicted in Figure 1 . After coating, the $\mathrm{CSC}+\mathrm{CPS}$ and polyester (CPS) coatings were smoother than the other ones, probably due to rigid film formation on the wood surface (Gholamiyan et al., 2012). After weathering, the surface roughness increased for all coatings expect $\mathrm{CZ}$. Increase in the surface roughness of wood after weathering is believed to be due to the erosion of primary cell wall caused by lignin degradation (Bulcke et al., 2007; Meincken and Evans, 2009). It is claimed that the surface roughness of nano- 
Table 4 Guide for coating systems

Tablica 4. Oznake sustava premaznih materijala

\begin{tabular}{|c|c|c|c|c|c|c|c|c|}
\hline \multicolumn{2}{|c|}{ Coating type /Vrsta premaznog materijala } & Control & $\mathbf{C Z}$ & $\mathbf{C Z F}$ & CZZF & CPS & CSC & CSC+CPS \\
\hline \multirow{3}{*}{$L^{*}$} & Before / prije & $\begin{array}{l}80.5 \\
(1.5)\end{array}$ & $\begin{array}{l}75.6 \\
(1.8)\end{array}$ & $\begin{array}{c}79 \\
(1.3)\end{array}$ & $\begin{array}{l}77.6 \\
(2.2)\end{array}$ & $\begin{array}{l}76.1 \\
(3.9)\end{array}$ & $\begin{array}{l}74.7 \\
(2.5)\end{array}$ & $\begin{array}{l}78.1 \\
(1.0)\end{array}$ \\
\hline & After / nakon & $\begin{array}{l}73.2 \\
(2.3) \\
\end{array}$ & $\begin{array}{l}74.2 \\
(1.6) \\
\end{array}$ & $\begin{array}{l}70.7 \\
(2.8) \\
\end{array}$ & $\begin{array}{l}73.3 \\
(0.6) \\
\end{array}$ & $\begin{array}{l}69.3 \\
(2.1) \\
\end{array}$ & $\begin{array}{l}65.4 \\
(1.2)\end{array}$ & $\begin{array}{l}67.5 \\
(0.4) \\
\end{array}$ \\
\hline & Mean changes / prosječna promjena & -7.2 & -1.3 & -8.2 & -4.3 & -6.7 & -9.2 & -10.5 \\
\hline \multirow{3}{*}{$a^{*}$} & Before / prije & $\begin{array}{c}3.5 \\
(0.3)\end{array}$ & $\begin{array}{c}2.8 \\
(0.8)\end{array}$ & $\begin{array}{c}3.8 \\
(0.9)\end{array}$ & $\begin{array}{c}4 \\
(0.7)\end{array}$ & $\begin{array}{c}4.8 \\
(0.5)\end{array}$ & $\begin{array}{c}5.1 \\
(0.8)\end{array}$ & $\begin{array}{c}3.6 \\
(0.6)\end{array}$ \\
\hline & After / nakon & $\begin{array}{c}9.5 \\
(0.1)\end{array}$ & $\begin{array}{c}9.8 \\
(0.5)\end{array}$ & $\begin{array}{l}11.4 \\
(0.4)\end{array}$ & $\begin{array}{c}8.7 \\
(0.7)\end{array}$ & $\begin{array}{l}11.7 \\
(0.6)\end{array}$ & $\begin{array}{l}13.8 \\
(0.6)\end{array}$ & $\begin{array}{l}13.1 \\
(0.5)\end{array}$ \\
\hline & Mean changes / prosječna promjena & 5.9 & 7 & 7.6 & 4.7 & 6.9 & 8.6 & 9.4 \\
\hline \multirow{3}{*}{$b^{*}$} & Before / prije & $\begin{array}{l}19.1 \\
(0.3)\end{array}$ & $\begin{array}{l}20.8 \\
(0.6)\end{array}$ & $\begin{array}{l}20.4 \\
(1.8)\end{array}$ & $\begin{array}{l}22.5 \\
(0.2)\end{array}$ & $\begin{array}{l}25.6 \\
(1.3)\end{array}$ & $\begin{array}{l}25.7 \\
(1.6)\end{array}$ & $\begin{array}{l}23.2 \\
(2.1)\end{array}$ \\
\hline & After/nakon & $\begin{array}{l}34.2 \\
(0.7)\end{array}$ & $\begin{array}{l}38.8 \\
(2.6) \\
\end{array}$ & $\begin{array}{l}38.4 \\
(0.3)\end{array}$ & $\begin{array}{l}36.6 \\
(0.8)\end{array}$ & $\begin{array}{l}42.1 \\
(2.6)\end{array}$ & $\begin{array}{l}46.7 \\
(1)\end{array}$ & $\begin{array}{l}44.9 \\
(1.0)\end{array}$ \\
\hline & Mean changes / prosječna promjena & 15.1 & 17.9 & 17.9 & 14 & 16.42 & 20.9 & 21.7 \\
\hline
\end{tabular}

Values in parentheses represent the standard deviation / Vrijednosti u zagradama standardne su devijacije.

Table 5 Changes of $\Delta E, c^{*}$ and $h^{*}$ before and after weathering

Tablica 5. Promjene $\Delta E, c^{*}$ and $h^{*}$ prije i nakon izlaganja vremenskim utjecajima

\begin{tabular}{|c|c|c|c|c|c|c|c|c|}
\hline \multicolumn{2}{|c|}{ Coating type /Vrsta premaznog materijala } & Control & $\mathbf{C Z}$ & $\mathbf{C Z F}$ & CZZF & CPS & CSC & CSC+CPS \\
\hline \multirow{3}{*}{$\Delta E^{*}$} & Before / prije & $\ldots$ & $\begin{array}{c}2.1 \\
(0.6)\end{array}$ & $\begin{array}{c}2.2 \\
(0.2)\end{array}$ & $\begin{array}{l}4.5 \\
(0.4)\end{array}$ & $\begin{array}{c}8 \\
(0.5)\end{array}$ & $\begin{array}{c}9 \\
(0.1)\end{array}$ & $\begin{array}{c}4.7 \\
(0.1)\end{array}$ \\
\hline & After / nakon & $\ldots$ & $\begin{array}{c}4.6 \\
(0.5)\end{array}$ & $\begin{array}{c}5.2 \\
(0.8)\end{array}$ & $\begin{array}{c}2.4 \\
(0.8)\end{array}$ & $\begin{array}{c}9 \\
(0.7)\end{array}$ & $\begin{array}{l}15.3 \\
(0.9)\end{array}$ & $\begin{array}{l}12.5 \\
(0.8)\end{array}$ \\
\hline & Mean changes / prosječna promjena & & 2.4 & 3.1 & -2 & 0.9 & 6.2 & 7.8 \\
\hline \multirow{3}{*}{$\mathrm{c}^{*}$} & Before / prije & $\begin{array}{l}19.4 \\
(1.5)\end{array}$ & $\begin{array}{c}21 \\
(1.6)\end{array}$ & $\begin{array}{l}20.8 \\
(2.5)\end{array}$ & $\begin{array}{l}22.9 \\
(1.6)\end{array}$ & $\begin{array}{l}26.1 \\
(2)\end{array}$ & $\begin{array}{l}26.3 \\
(1.8)\end{array}$ & $\begin{array}{l}23.5 \\
(1.6)\end{array}$ \\
\hline & After / nakon & $\begin{array}{l}35.5 \\
(2.1)\end{array}$ & $\begin{array}{l}40.0 \\
(2.9)\end{array}$ & $\begin{array}{l}40.1 \\
(3.2)\end{array}$ & $\begin{array}{l}37.6 \\
(2.1)\end{array}$ & $\begin{array}{l}43.7 \\
(2.5)\end{array}$ & $\begin{array}{l}48.7 \\
(3)\end{array}$ & $\begin{array}{l}46.8 \\
(3.6)\end{array}$ \\
\hline & Mean changes / prosječna promjena & 16.1 & 18.9 & 19.2 & 14.7 & 17.5 & 22.4 & 23.2 \\
\hline \multirow{3}{*}{$h^{*}$} & Before / prije & $\begin{array}{c}1.3 \\
(0.3)\end{array}$ & $\begin{array}{c}1.4 \\
(0.1)\end{array}$ & $\begin{array}{c}1.3 \\
(0.1)\end{array}$ & $\begin{array}{c}1.3 \\
(0.2)\end{array}$ & $\begin{array}{c}1.3 \\
(0.2)\end{array}$ & 1. $(0.13)$ & $\begin{array}{c}1.4 \\
(0.2)\end{array}$ \\
\hline & After / nakon & $\begin{array}{c}1.2 \\
(0.1)\end{array}$ & $\begin{array}{c}1.3 \\
(0.1)\end{array}$ & $\begin{array}{c}1.2 \\
(0.2)\end{array}$ & $\begin{array}{c}1.3 \\
(0.1)\end{array}$ & $\begin{array}{c}1.2 \\
(0.1)\end{array}$ & $\begin{array}{c}1.2 \\
(0.2)\end{array}$ & $\begin{array}{c}1.2 \\
(0.1)\end{array}$ \\
\hline & $\begin{array}{c}\text { Mean changes } \\
\text { prosječna promjena }\end{array}$ & -0.09 & -0.1 & -0.1 & -0.06 & -0.09 & -0.09 & -0.1 \\
\hline
\end{tabular}

Values in parentheses represent the standard deviation / Vrijednosti u zagradama standardne su devijacije.

coatings is not significantly affected by weathering because of small size and high surface to volume ratio of nanoparticles ( $\mathrm{Li}$ et al., 2001). Thus, the smaller size of nano-zycosil particles $(10-30 \mathrm{~nm})$ compared to nanozycofil (90-300 nm) ones may play an important role in the surface roughness.

\subsection{Wettability}

3.3. Kvašenje

The results showed that the wettability of wood decreased due to coating by all used coating systems (Figure 2), and the contact angle was increased significantly with the applied coatings. However, weathering had a decreasing effect on the contact angle for all coatings. The contact angle on the control sample dropped from $43^{\circ}$ to $38^{\circ}$ after $1440 \mathrm{~h}$ weathering and that of $\mathrm{CZ}$ from $87^{\circ}$ to $67^{\circ}$. Among coatings, $\mathrm{CZ}$ and $\mathrm{CSC}+\mathrm{CPS}$ exhibited the highest contact angle after the weathering exposure. In agreement with our results, waterproofing of organosilane nanomaterials has been reported, previously (Tshabalala and Gangstad, 2003; Godnjavec et al., 2012).

\subsection{SEM and EDX analysis}

3.4. SEM i EDX analiza

Scanning electron microscopy (SEM) images of control and nano-zycosil coated films are shown in Figure 3. As can be seen in Figure 4, most particles are in nanometric dimensions $(<100 \mathrm{~nm})$. SEM images confirm that silane nanoparticles can effectively cover the wood surface after coating, which is similar to the results reported by a number of previous researchers (Li et al., 2010; Da Silva et al., 2012; Mahltig et al., 2010). A significant silane peak in the EDX spectra of organosilane coated specimens confirms the presence of nano-zycosil or nano-zycofil particles (Figure 5).

\subsection{Surface chemistry}

3.5. Kemijska svojstva površine

The ATR-FTIR spectra of nano-zycosil coated and uncoated specimens are compared in Figure 6. The absorption bands at $1110-1090 \mathrm{~cm}^{-1}, 810-800 \mathrm{~cm}^{-1}$ and $480-470 \mathrm{~cm}^{-1}$ are attributed to the $\mathrm{Si}-\mathrm{O}-\mathrm{Si}$ asymmetric stretching, symmetric stretching and bending vibration, respectively. The spectrum of coated specimen 
. Gholamiyan, Tarmian: Weathering Resistance of Poplar Wood Coated by Organosilane...
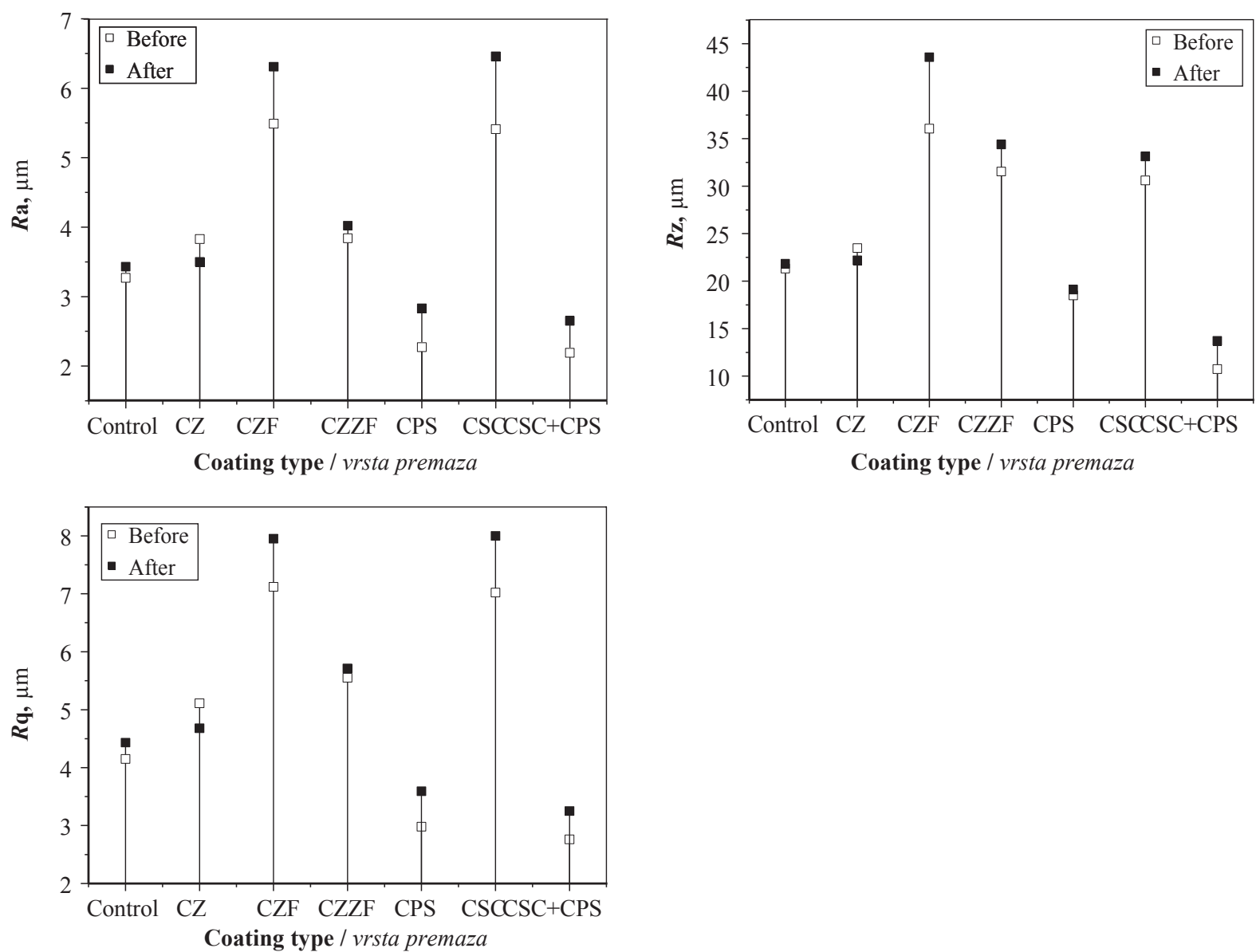

Figure 1 Surface roughness parameters for coated and uncoated specimens before and after weathering

Slika 1. Parametri hrapavosti površine premazanih i nepremazanih uzoraka prije i nakon izlaganja vremenskim utjecajima
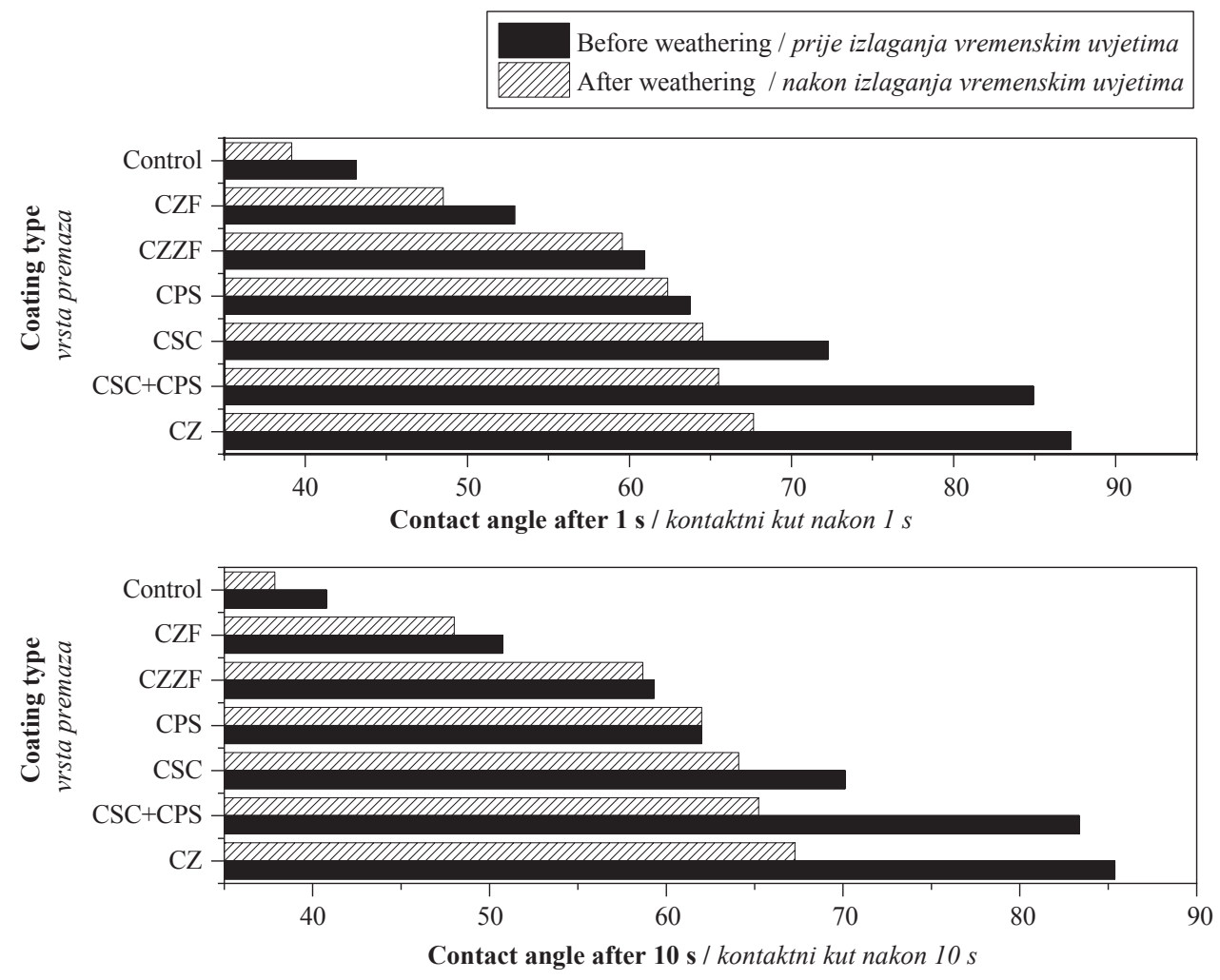

Figure 2 Contact angles for coated and uncoated specimens before and after weathering

Slika 2. Kontaktni kut premazanih i nepremazanih uzoraka prije i nakon izlaganja vremenskim utjecajima 

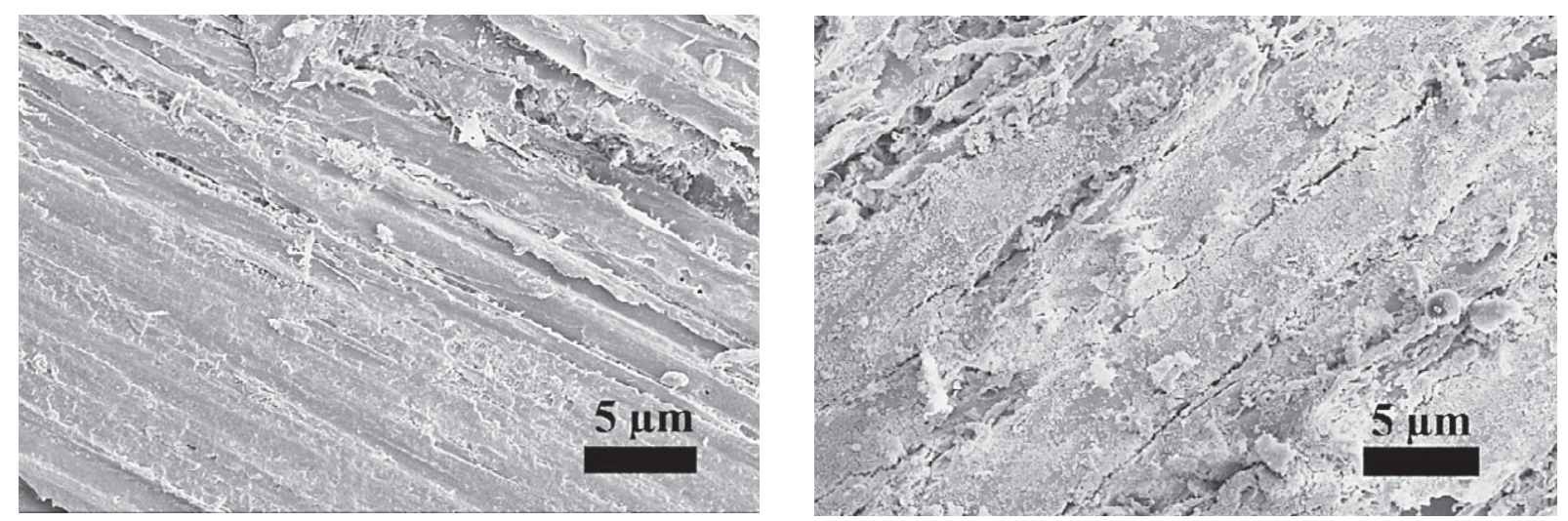

Figure 3 SEM image of control (left) and nano-zycosil (right) coating

Slika 3. SEM fotografija kontrolnog premaza (lijevo) i premaza nano-zycosilom (desno)

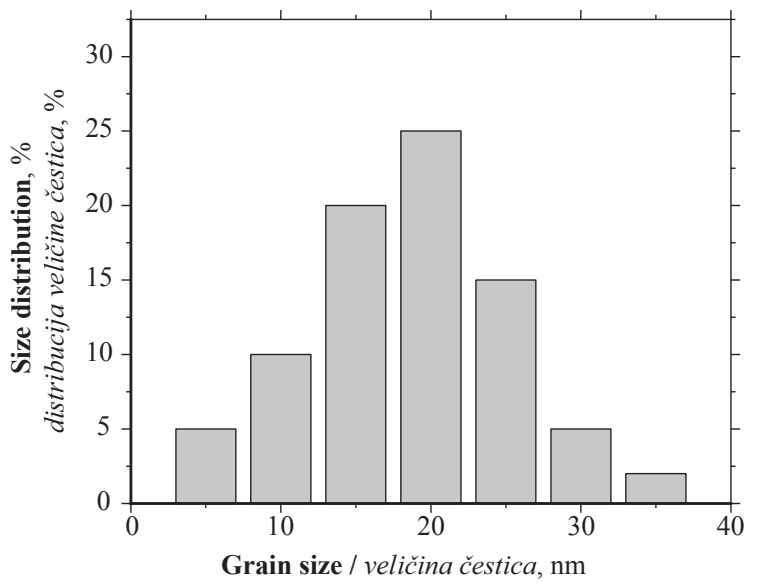

Figure 4 Particles size distribution of nano-zycosil

Slika 4. Raspodjela veličine čestica nano-zycosila

shows bands resulting from $\mathrm{Si}-\mathrm{CH}_{3}$ bonds $\left(1269 \mathrm{~cm}^{-1}\right)$ (Tshabalala and Gangstad, 2003). The bands at broad absorption band of $3445-3425 \mathrm{~cm}^{-1}$ and $1640-1630$ $\mathrm{cm}^{-1}$ are due to $-\mathrm{OH}$ groups of silane coatings (Rao et al., 2010). In addition, the weak bands centered around $2880 \mathrm{~cm}^{-1}$ due to the $\mathrm{C}-\mathrm{H}$ stretch and $1460 \mathrm{~cm}^{-1}$ due to the $\mathrm{C}-\mathrm{H}$ bending vibrations of the wood components were replaced by sharper and much stronger bands at $2921 \mathrm{~cm}^{-1}$ due to the $\mathrm{C}-\mathrm{H}$ bending vibrations of the long hydrocarbon chain bound to the wood by the nano-zycosil coating (Tshabalala and Gangstad, 2003 and Wang et al., 2011).

\section{CONCLUSIONS}

4. ZAKLJUČAK

SEM images and EDX spectra showed that the wood surfaces can be effectively coated by the organosilane water soluble nanomaterials. SEM images revealed a significant surface coverage by the nanoparticles, and the EDX analysis also confirmed the presence of silane in the organosilane coated specimens. Among coating materials, nano-zycosil (CZ) exhibited the best performance for improving the weathering resistance of poplar wood. Different color parameters were observed between nano-zycosil and nano-zycofil coat-

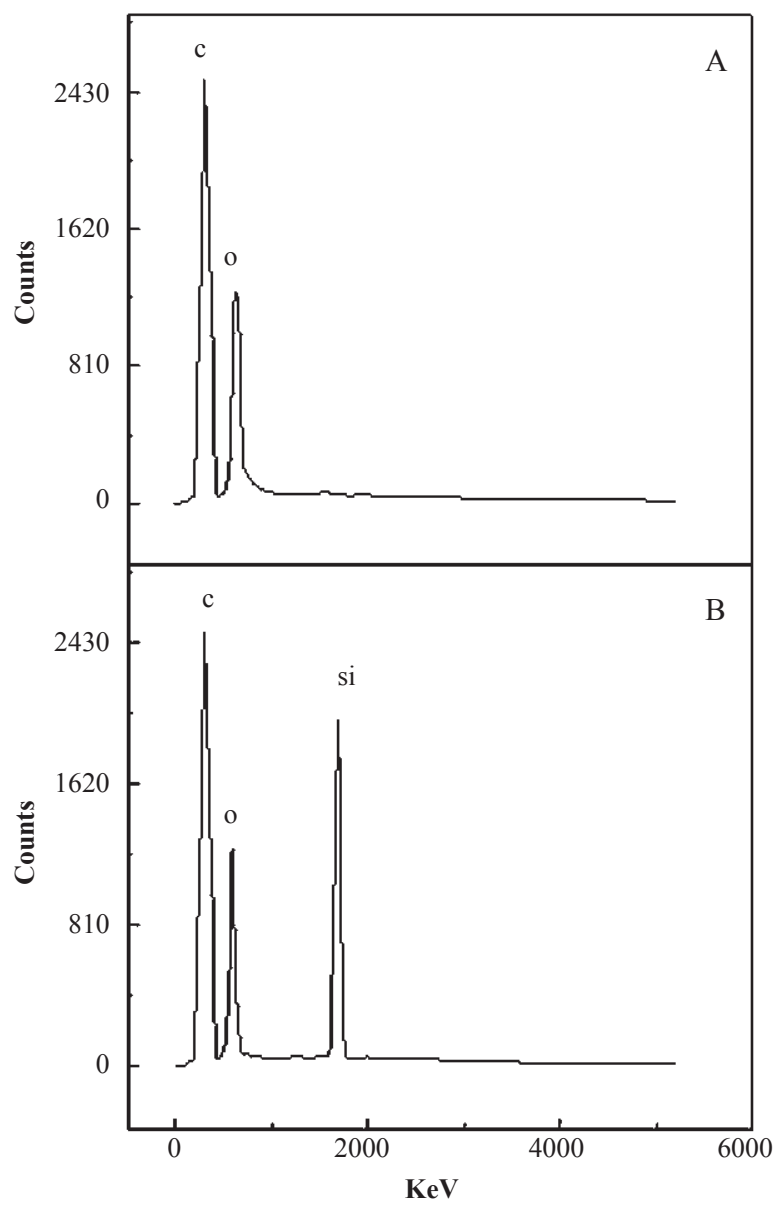

Figure 5 EDX spectra of (A) control and (B) nano-zycosil coated surfaces

Slika 5. EDX spektar (A) kontrolne površine i (B) površine premazane nano-zycosilom

ings. After weathering, all coatings except $\mathrm{CZ}$ and CZZF were darker than the uncoated wood. Compared to the clear coatings, the roughness of nano-zycosil and nano-zycofil was less affected by weathering, and the former showed a better performance. This can be due to the very small size and high surface to volume ratio of nanoparticles. Further researches on the nanofilm formation using sol-gel method are recommended for improving the weathering resistance of wood surfaces. 


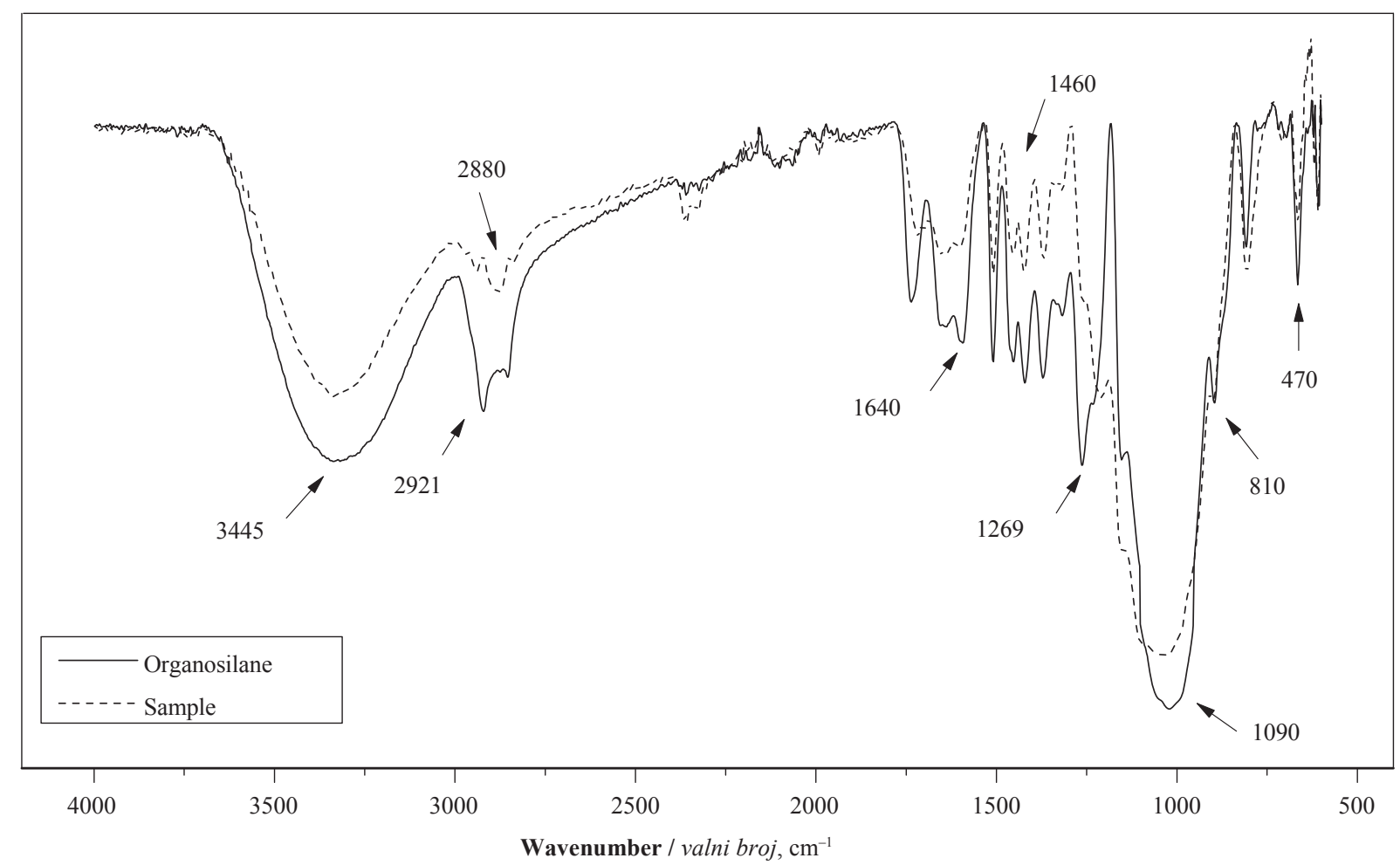

Figure 6 ATR-FTIR spectra for control and organosilane coated surfaces

Slika 6. ATR-FTIR spektar kontrolne površine i površine obrađene organosilanom

\section{Acknowledgements - Zahvala}

The authors thank the Iranian National Science Foundation and the Institute of Wood Biology and Technology, University of Gottingen, Germany.

\section{REFERENCES}

\section{LITERATURA}

1. Bulcke, J.; Acker, J.; Saveyn, H.; Stevens, M., 2007: Modelling film formation and degradation of semi-transparent exterior wood coatings. Progress in Organic Coatings, 58: 1-12. https://doi.org/10.1007/s11998-007-9074-4.

2. Bulian, F.; Graystone, J., 2009: Wood Coatings Theory and Practice. Elsevier Science Ltd. 320.

3. Bulian, F.; Collavini, F.; Matellon, A., 2017: Investigating the effects of weathering on wood coatings. FME Transactions. 45, 405-411. https://doi:10.5937/fmet1703405B.

4. Busseya, D.; Perinab, V.; Jonesa, F.; Cechc, V., 2018: Effect of chemical modification on the mechanical properties of plasma-polymerized organosilicones. Progress in Organic Coatings, 119: 85-90. https://doi.org/10.1016/j.porgcoat.2018.02.020.

5. Chang, S. T.; Chou, P. L., 1999: Photodiscoloration of UV-curable acrylic coatings and the underlying wood. Polymer Degradation and Stability, 63: 435-444. https://doi.org/10.1016/S0141-3910(98)00124-4.

6. Clausen, C.; Green, F.; Kartal, S., 2010: Weatherability and Leach Resistance of Wood Impregnated with NanoZinc Oxide. Nanoscale Research Letters, 5: 1464-1467. https://doi.org/10.1007/s11671-010-9662-6.

7. Dasari, A.; Yu, Z.; Mai, Y., 2009: Fundamental aspects and recent progress on wear/scratch damage in polymer nanocomposites. Materials Science and Engineering: R: Reports, 63: 31-80. https://doi.org/10.1016/j.mser.2008.10.001

8. Da Silva, M.; Santilli, C.; Pulcinelli, S., 2012: Wettability and photodegradation activity of sol-gel dip-coated zinc oxide films. Journal of Sol-Gel Science and Technology, 63: 230-234. https://doi.org/10.1007/s10971-012-2721-y.

9. Fengel, D.; Wegener, G., 1984: Wood: chemistry, ultrastructure, reactions. Berlin and New York, Walter de Gruyter, 613.

10. Gholamiyan, H.; Tarmian, A.; Doost Hosseini, K.; Azadfallah, M., 2012: Modification of moisture diffusion behavior of wood by clear coatings and nanoparticles. Maderas: Ciencia y Tecnología, 14: 43-52. https://doi. org/10.4067/S0718-221X2011000200004.

11. Gholamiyan, H.; Tarmian, A.; Ranjbar, Z.; Abdulkhani, A.; Azadfallah, M.; Mai, C., 2016: Silane nanofilm formation by sol-gel processes for promoting adhesion of waterborne and solvent-borne coatings to wood surface. Holzforschung, 70(5): 429-437. https://doi.org/10.1515/ hf-2015-0072.

12. Godnjavec, J.; Znoj, B.; Vince, J.; Steinbucher, M.; Znidarsic, A.; Venturini, P., 2012: Stabilization of rutile $\mathrm{TiO}_{2}$ nanoparticles with glymo in polyacrylic clear coating. Materials and Technology, 46 (1): 19-24.

13. International Organization for Standardization (ISO), 1997: Geometrical product specifications (GPS) - Surface texture: Terms definitions and surface texture parameters. Technical Report ISO 4287, International Organization for Standardization, Geneva.

14. Li, F.; Hu, K.; Li, J.; Zhao, B., 2001: The friction and wear characteristics of nanometer $\mathrm{ZnO}$ filled polytetrafluoroethylene. Wear, 249: 877-882. https://doi.org/10.1016/S0043-1648(01)00816-X.

15. Li, Q.; Chen, Y.; Zeng, D.; Gao, W.; Wu, Z., 2005: Photocatalytic characterization of silica coated titania nanoparticles with tunable coatings. Journal of Nanoparticle Research, 7: 295-299.

https://doi.org/ 10.1007/s11051-004-5944-1. 
16. Lung Chou, P.; Ting Chang, H.; Feng Yeh, T.; Tzen Chang, S. H., 2008: Characterizing the conservation effect of clear coatings on photodegradation of wood. Bioresource Technology, 99: 1073-1079.

https://doi.org/ 10.1016/j.biortech.2007.02.027.

17. Mahltig, B.; Arnold, M.; Lothman, P., 2010: Surface properties of sol-gel treated thermally modified wood. Journal of Sol-Gel Science and Technology, 55: 221-227. https://doi.org/10.1007/s10971-010-2236-3.

18. Meincken, M.; Evans, P., 2009: Nanoscale characterization of wood photodegradation using atomic force microscopy. European Journal of Wood and Wood Products, 67: 229-231. https://doi.org/10.1007/s00107-008-0305-x.

19. Mori, T.; Tanaka, K.; Inomata, T.; Takeda, A.; Kogoma, M., 1998: Development of silica coating methods for powdered pigments with atmospheric pressure glow plasma. Thin Solid Films, 316: 89-92. https://doi.org/10.1016/S0040-6090(98)00395-2.

20. Nanetti, P., 2006: Coatings from A to Z. Vincentz Network, Germany, Hannover.

21. Pastore, T.; Santos, K.; Rubim, J. A., 2004: Spectrocolorimetric study on the effect of ultraviolet irradiation of four tropical hardwoods. Bioresource Technology, 93: 37-42. https://doi.org/10.1016/j.biortech.2003.10.035.

22. Nguyen-Tri, P.; Nguyen, T.; Carriere, P.; Ngo Xuan, C., 2018: Nanocomposite Coatings: Preparation, Characterization, Properties, and Application. International Journal of Corrosion, 2018: 1-19. https://doi.org/10.1155/2018/4749501.

23. Powell, Q.; Fotou, G.; Kodas, T.; Anderson, B., 1997: Synthesis of alumina- and lumina/silica-coated Titania particles in an aerosol flow reactor. Chemistry of Materials, 9: 685-693. https://doi.org/10.1021/cm960334g.

24. Rao, A. V.; Gurav, A. B.; Latthe, S. S.; Vhatkar, R. S.; Kappenstein, C.; Wagh, P. B.; Gupta, S. C., 2010: Water repellent porous silica films by sol-gel dip-coating method. Journal of Colloid and Interface Science, 352: 30-35. https://doi.org/10.1016/j.jcis.2010.08.003.

25. Sigh, R.; Tomer, N.; Bhadraiah, S., 2001: Photo-oxidation studies on polyurethane coating: effect of additives on yellowing of polyurethane. Polymer Degradation and Stability, 73: 443-446.

https://doi.org/10.1016/S0141-3910(01)00127-6.
26. Taghiyari, H., 2013: Nano-zycosil in MDF: gas and liquid permeability. European Journal of Wood and Wood Products, 71: 353-360. https://doi.org/ 10.1007/s00107-013-0691-6.

27. Tshabalala, M.; Gangstad, J., 2003: Accelerated Weathering of Wood Surfaces Coated with multifunctional Alkoxysilanes by Sol-Gel Deposition. Journal of Coatings Technology, 75: 37-43. https://doi.org/ 10.1007/BF02730098.

28. Tsuchikawa, S.; Murata, A.; Kohara, M.; Itsui, K., 2003: Spectroscopic monitoring of biomass modification by light-irradiation and heat treatment. Journal of Near Infrared Spectroscopy, 11 (5): 401-405. https://doi.org/10.1255/jnirs.391.

29. Veronovski, N.; Verhovsek, D.; Godnjavec, J., 2013: The influence of surface-treated nano-TiO2 (rutile) incorporation in water-based acrylic coatings on wood protection. Wood Science and Technology, 47: 317-328. https:// doi.org/10.1007/s00226-012-0498-3.

30. Vlad Cristea, M.; Riedl, B.; Blanchet, P., 2011: Effect of addition of nanosized UV absorbers on the physico-mechanical and thermal properties of an exterior waterborne stain for wood. Progress in Organic Coatings, 72: 755762. https://doi.org/10.1016/j.porgcoat.2011.08.007.

31. Wang, S.; Liu, C.; Liu, G.; Zhang, M.; Li, J.; Wang, C., 2011: Fabrication of superhydrophobic wood surface by a sol-gel process. Applied Surface Science, 258: 806810. https://doi.org/10.1016/j.apsusc.2011.08.100.

32. Xu, B.; Cai, Z., 2008: Fabrication of a superhydrophobic $\mathrm{ZnO}$ nanorod array film on cotton fabrics via a wet chemical route and hydrophobic modification. Applied Surface Science, 254 (18): 5899-5904. https://doi.org/10.1016/j.apsusc.2008.03.160.

\section{Corresponding address:}

\section{Dr. HADI GHOLAMIYAN}

Department of Wood and Paper Science \& Technology Faculty of Natural Resources

University of Tehran

4111 Karaj, IRAN

e-mail: Hadi_Gholamiyan@ut.ac.ir 